\title{
From Tone to Tune-Carl Stumpf and the Violin
}

\author{
JULIA KURSELL
}

\section{INTRODUCTION}

The first volume of Carl Stumpf's Tonpsychologie (Tone Psychology, 1883) opens with a confession. "In my youth I passionately practiced music, and I even meant to find in it my vocation," the philosopher wrote. ${ }^{1}$ He hastened to add that Franz Brentano's lectures soon took him elsewhere. Brentano's rigorous thought about sensation attracted Stumpf, and he eventually saw an opportunity to combine his philosophical interests and his love of music in psychology. When he followed Brentano as professor of philosophy in Würzburg in 1873, he

\footnotetext{
The author wishes to thank David Trippett, the editor of this special volume, for tremendous support.

${ }^{1}$ Carl Stumpf, Tonpsychologie, 2 vols. (Leipzig: Hirz, 1883 , 1890). The two volumes are quoted in the following as TP with Roman and Arabic numerals for volume and quoted page respectively. Where possible, the translation by Robin Rollinger is used. For providing access to it, I wish to thank David Trippett.
}

began carrying out experiments on the perception of tones. ${ }^{2}$

Stumpf is widely known for having initiated the field of music psychology, but even more so for having laid the ground for the Berlin Gestalt School of Psychology, in his capacity

\footnotetext{
${ }^{2}$ For biographical information on Stumpf, see, e.g., Carl Stumpf, Selbstbeschreibung (Leipzig: Meiner, 1924); translated as "Carl Stumpf: A Self-Portrait," in Carl Stumpf, The Origins of Music, ed. and trans. David Trippett (Oxford: Oxford University Press, 2012), 189-252; Helga Sprung and Lothar Sprung, Carl Stumpf: Eine Biografie: Von der Philosophie zur Experimentellen Psychologie (Munich: Profil, 2006).

${ }^{3}$ On Stumpf as philosopher, see, e.g., Denis Fisette, "Carl Stumpf," The Stanford Encyclopedia of Philosophy (spring 2019 edition), Edward N. Zalta, https://plato.stanford.edu/ archives/spr2019/entries/stumpf/ (accessed on 1 April 2019), including further references on the various positions toward his work as belonging to the traditions of Brentano's philosophy, phenomenology, Gestalt theory; for further nuanced views in this matter, see Mitchell G. Ash, Gestalt Psychology in German Culture, 1890-1967: Holism and the Quest for Objectivity (Cambridge: Cambridge
} 
as director of the Institute of Psychology at Friedrich-Wilhelm University in Berlin-a position he held between 1894 and 1921. Wolfgang Köhler, Kurt Koffka, and Kurt Lewin obtained their doctoral degrees at the Institute; Max Wertheimer spent time as associated researcher there. Stumpf's concept of "complex qualities" (Komplexqualitäten) ${ }^{4}$ contributed to the rise of Gestalt psychology in Germany. As opposed to, for instance, Christian von Ehrenfels, who used melody as his prime example in the seminal 1890 paper "Über Gestaltqualitäten" (On the Qualities of Gestalt), Stumpf did not resort to melody as an example for his concept of complex qualities. Although he devoted more than half of his scholarly output to music, melody is discussed only in passing. Stumpf's focus on tones rather than tunes even led him to mistaking the one for the other in Edmund Gurney's The Power of Sound (1880), when he reviewed this book for the newly established journal Vierteljahrsschrift für Musikwissenschaft in $1885 .{ }^{5}$

The very question of how we read what we want into what we get became the central topic of Stumpf's work over the years. It provides a red thread through his "heterogeneous body of writing. ${ }^{\prime 6} \mathrm{He}$ asked how our minds are set to what we perceive. In the following article, the question will be reversed; I ask whether we can trace music as mindset in the first volume of Stumpf's Tone Psychology. His references to musical practice and, more specifically, to his own musical upbringing will be used as a heuristic guide. Stumpf's preferred instrument gives important hints to understanding his work on music: this instrument was the violin.

University, 1995), and Riccardo Martinelli, "A Philosopher in the Lab: Carl Stumpf on Philosophy and Experimental Sciences," Philosophia Scientiæ 19:3 (2015): 23-43.

${ }^{4}$ The term appears in Carl Stumpf and Erich M. von Hornbostel, "Über die Bedeutung ethnologischer Untersuchungen für die Psychologie und Ästhetik der Tonkunst," Beiträge zur Akustik und Musikwissenschaft 6 (1911): 102-15, here 107, and Carl Stumpf, Die Sprachlaute: Experimentell-Phonetische Untersuchungen nebst einem Anhang über Instrumentalklänge (Berlin: Springer, 1926), vi. ${ }^{5}$ Edmund Gurney, The Power of Sound (London: Smith, Elder \& Co., 1880|; Carl Stumpf, "Musikpsychologie in England: Betrachtungen über Herleitung der Musik aus der Sprache und aus dem thierischen Entwickelungsprocess, über Emprismus und Nativismus in der Musiktheorie," Vierteljahrsschrift für Musikwissenschaft 1 (1885): 261-349.

${ }^{6}$ Martinelli, "A Philosopher in the Lab," 24.
The violin affords neither a ready-made distribution of pitches nor a mechanism of sound production. Both must be taken care of by the player. In contrast, the piano with its display of the tonal range and efficient mechanical action not only solves these issues in advance, but also served many authors in the nineteenth century as a model in their descriptions both of music theory and of the functions of hearing in human physiology. Such a function of the piano is conspicuously absent in Stumpf's writings. Yet his references to the violin are not straight forward. The fact that a violin cannot be played without some prior conception of what to do with the instrument and which tones to aim for does not lend itself easily to modeling. But it is exactly the interplay of concept and action that was of interest for his query into the workings of the musical mind.

The guiding hypothesis of this article is that, while Stumpf always focused on the listening subject, he nevertheless modeled listening according to the necessity of building up some cognitive framework as this is proposed in violin pedagogy. This assumption will be elaborated upon in three steps. The first part briefly sketches the state of violin pedagogy in the first half of the nineteenth century with particular focus on the aspect of how cognition and bodily mechanics relate in it. The second part introduces some of Stumpf's explicit references to the violin. This part is subdivided in three subsections that discuss the role of muscle memory, the relevance of talent, and the mental grid of the violin player as constituting the experimental approach developed in the first volume of the Tone Psychology. The last part will zoom in on the misread passage about tune to discuss, by way of conclusion, why Stumpf abstained from melody as an object of inquiry.

\section{Violin Pedagogy}

Born in 1848, Stumpf began playing the violin at the age of seven, which situates his first contact with the instrument in the mid-1850s. In an autobiographical essay, he furthermore reports that the grammar school, which he attended from the age of eleven, offered music teaching for free and maintained its own orchestra. By then, he had already learned sight singing from the missals he got to see as an altar boy. He mentioned 
that, in addition to the violin, he learned five more instruments with mixed success, and that he made public appearances with the violin during his years of study. ${ }^{7}$ Add to this a father and mother who were a good singer and gifted pianist, respectively, and it becomes clear his musical upbringing was securely embedded within the typical middle-class music culture of his time.

Stumpf's account, although scarce on the process of learning itself, is nevertheless telling. Written in 1924, his autobiography clearly emphasizes that the child became thoroughly acquainted with the system of tonal relations through learning to sight-read choral notation parallel to acquiring playing skills, and the youth used the combined cognitive and motor skills for transferring it to different instruments. To be sure, his talent seems to have exceeded that of the regular middle-class music lover. He also reports that he was in charge of the chamber music in his parents' home, which enabled him to become familiar with what might be called analytical ways of listening to polyphonic and formal structures in music.

Stumpf's musical education, more specifically, may be situated at a historical moment, when violin playing had undergone a certain degree of standardization. Technical features, such as the concave Tourte-style bow and the chin rest, were by then firmly established. More important than these technical affordances for virtuoso playing, however, are the accounts of how the pupil should learn to play. In the area of instrumental pedagogy, the nineteenth century saw considerable change. By the 1850 s, the professionalization of musical training was well underway. That process had begun half a century earlier with the foundation of the Paris Conservatoire, and it would continue over the entire century.

Music education participates in the grand narrative of industrializing Western societies that involves standardization of production and knowledge. There are characteristic differences among the instruments, however. The instrument that is held to epitomize the narrative is not the violin, but the piano, and thus an

\footnotetext{
${ }^{7}$ See on the violin and music more generally in Stumpf's early years: Selbstbeschreibung / "A Self-Portrait," 190-91.
}

instrument that addresses the music lover at home, the virtuoso on stage or the theorist, teacher, or composer who use the instrument for probing the sounds of harmony. The fortepiano also marks the transition from a basso continuo to orchestral setting. In an orchestra, the piano is seldom needed; enriching the palette of timbres, it re-enters only in the late nineteenth century.

Parallel to this shift in function in keyboard instruments, the career of the piano also offers a story of deskilling that involves piano teaching and instrument building. In production processes, deskilling refers to the emerging mass production, in which the single worker needs less and less knowledge about the production process and functioning of the object produced. ${ }^{8}$ This not only applies to the mass production of pianos, but a story of deskilling also returns in piano playing. It runs from the drill of the pupils' hands in the first half of the century to the discourse that includes Eduard Hanslick's complaints about a piano epidemic and the heavy marketing for the player piano as the device that finally freed music lovers from the necessity to acquire playing skills or knowledge in music theory.?

The violin tells quite a different story. String playing is portrayed as human rather than mechanical. Goethe's comparison of the string quartet to a conversation among four reasonable people is a topos. ${ }^{10}$ The violin in particular is often compared to the singing voice in its natural intonation. Violin players also invited contradictory attributions. In the figure of Niccolò Paganini, the violinist rose to a cliché of demonized virtuoso, while

\footnotetext{
${ }^{8}$ I take the term "deskilling" from Myles W. Jackson, Harmonious Triads: Physicists, Musicians, and Instrument Makers in Nineteenth-Century Germany (Cambridge, MA: MIT Press, 2006), 152.

${ }^{9}$ See e.g., Wolfgang Scherer, Klavier-Spiele: Die Psychotechnik der Klaviere im 18. und 19. Jahrhundert (Munich: Fink, 1989); Roger Moseley, Keys to Play: Music as a Ludic Medium from Apollo to Nintendo /Oakland: University of California Press, 2016); Alexandra Hui, The Psychophysical Ear: Musical Experiments, Experimental Sounds, 1840-1910 (Cambridge, MA: MIT Press, 2013); Sonja Petersen, Vom "Schwachstarktastenkasten" und seinen Fabrikanten: Wissensräume im Klavierbau, 1830-1930 (Münster: Waxmann, 2011); Arthur W. J. G. Ord-Hume, Pianola: The History of the Self-Playing Piano (London: George Allen \& Unwin, 1984).

${ }^{10}$ Letter to Zelter, 9 November 1829, MA 20.2, 1275.
} 
at the same time the growing orchestra resulted in the caricatured image of the rank and file musician who doubled the filling voices.

In fact, the rising demand for string players was explicitly acknowledged in music-educational circles around 1800. Founded "on the new democratic principle of education for the qualified, irrespective of social status,"11 the Conservatoire de Paris was the cradle of a new attitude toward professional skill formation. This, of course, included violin teaching. The Méthode du Violon (1793), co-authored by Pierre Rode, Rodolphe Kreutzer, and Pierre Baillot, opens with the following statement: "As we deal with the instrument that has become the most universal, and which due to its usefulness finds itself in the hands of the greatest number of musicians, it is necessary to bring everything to the students' attention that can give them a correct idea of it and helps them to provide this instrument with the rank it deserves." ${ }^{12}$ Violin pedagogy had to respond to diverging demands: orchestral music required large cohorts of musicians ready to play reliably, while the burgeoning solo and chamber music repertoires demanded refined musicianship. The manual is radically innovative in this respect. After a relatively short introduction it begins with an explanation about posture and movement: the "mechanism of the violin" (Du mécanisme du violon). To learn how to play the violin, one must take a violin and a bow and try to grasp what to do with them. This seems logical for a practical manual, but had been out of the question for, say, Leopold Mozart. His groundbreaking treatise Versuch einer gründlichen Violinschule (A Treatise on

\footnotetext{
${ }^{11}$ Natasha Loges and Colin Lawson, "The Teaching of Performance," in The Cambridge History of Musical Performance, ed. Colin Lawson and Robin Stowell (Cambridge: Cambridge University Press, 2012), 135-68, here 148. On the history of the Paris Conservatoire, see Le Conservatoire de Paris: Regards sur une institution et son histoire, ed. Emmanuel Hondré (Paris: Association du Bureau des Etudiants du Conservatoire National Supérieur de Musique de Paris, 1995).

${ }^{12}$ Pierre Rode, Rodolphe Kreutzer, Pierre Baillot, Méthode de violon (Paris, 1802), 1 (where not indicated otherwise, translations are mine): "Comme il s'agit ici de l'instrument devenu le plus universel, de celui qui par son utilité se trouve entre les mains du plus grand nombre de musiciens, il est nécessaire de faire connaître aux élèves tout ce qui peut leur en donner une idée juste, et les determiner à lui conserver le rang qui lui appartient."
}

the Fundamental Principles of Violin Playing, 1756) presented a different order of steps. ${ }^{13} \mathrm{He}$ insisted that the instrument should not be handed over to the apprentice before they knew the notes. Without the backing of an institution, the violin teacher had to teach these matters, as did Mozart père. After an extended introduction to the violin as a member of the string family and to music history, from its legendary origins to the present day, Leopold first expounded on the symbolic system of tonal music.

The first item in Mozart's Treatise that requires a concept of the violin as a physical object is a passing mention of the finger placement. The violin, the author explains in paragraph 13 of the first chapter (dedicated to note names), has four strings, each of which is "named" after one of the seven musical letters. In order to produce different notes, he continues, one needs to place the fingers on the strings. An example provides a diatonic scale that is distributed over the four strings. Precedence is given, however, to memorizing the note names at this point, as the ensuing paragraph confirms: "One clearly perceives the empty string indicated with a capital letter and the ensuing placements of fingers on the remaining notes, which the pupil must impress well on his memory: in order to know without seeing the letter on a note and without much deliberation which letter belongs to each note, wherever it is encountered."14

No mention of posture and movement is made, as the text goes on to explain rhythmic notation, barring and the "artificial" Italian terminology that indicates tempo, expression, and playing techniques, including the signs that facilitate economic notation such as da capo and dal segno. The sophisticated explanations of bowing that occur in the explanation of rhythm make it clear that the text addresses the master of a potential student, who may not yet be able to read music.

In the second chapter Leopold calls for action: "When the master finds after scrupulously

\footnotetext{
${ }^{13}$ Leopold Mozart, Versuch einer gründlichen Violinschule (Augsburg: Mozart-J. J. Lotter, 1756); idem, A Treatise on the Fundamentals of Violin Playing [1937], trans. Editha Knocker (Oxford: Oxford University Press, 1985).

${ }^{14}$ Mozart, Versuch, 26. My translation deviates from the 1937 translation (30), which suggests that this paragraph is about playing rather than note reading.
} 
inquiring after the pupil's knowledge of what has been expounded heretofore and the pupil has truly grasped and memorized it, then he [the master] places the violin into the pupil's left hand." ${ }^{15}$ How this should happen is explained by reference to three images of violin posture. Subtracting the voluminous clothes that seem to cover a belly unbecoming of the players' youthful heads, the postures indicate that the bowing arm should be kept close to the trunk and that the violin rests on the left clavicle. Although two postures are discussed as appropriate, the one that Mozart's father prefers would soon become obsolete through the regular use of the chin rest.

Mozart junior, born in the same year his father's Violinschule was published, would not be alone in soon overruling this order of things as one is tempted to assume. Half a century later, the Paris Conservatoire's matter-of-fact explanation of violin playing replaced Mozart senior's scruples with a different kind of thoroughness. Approved by the Conservatoire's assembly of members in its second revision through Pierre Baillot on " 5 ventôse, an 10" (24 February 1802), the tutor was intended as official doctrine. This bureaucratic regulation of violin playing nevertheless left little to be desired in terms of artistic expression. After providing a complete range of studies for the hand positions of the player, the manual approached ornamentation, bowing timbre, and intensity in an equally systematic manner, always providing study materials for the topic in question. The final part introduced notions of artistic expression, culminating in the explanation of the "genius of execution." This latter part summed up the qualities a player may achieve in bringing to life all the nuances of music, be they dictated by sentiment or technique, to eventually speak in the "language of the gods." ${ }^{\prime 16}$ This language could not be acquired by studying its lexical elements, which the young

\footnotetext{
${ }^{15}$ Mozart, Versuch, 53. English translation is again changed to emphasize that only now is the violin handed over to the student; the English translation suggests (54) that starting from now, it matters whether the student holds the instrument correctly. More literally, the text says "the violin is adjusted into the pupils left arm," which makes sense if one considers Leopold Mozart's preferred posture.

${ }^{16}$ Rode, Kreutzer, Baillot, Méthode de Violon, 163.
}

violinists were assumed to have understood by then, but by surmounting technical difficulties.

Two violin manuals from the 1830 s set a new standard, now addressing individual teaching for a growing middle class. Baillot published a manual of his own, L'Art du Violon (1835), while Louis Spohr's contemporary manual Violinschule (1833) equals Baillot's in fame. ${ }^{17}$ Baillot's title alluded to the eighteenth-century tradition in highlighting art rather than method, while Spohr typically remains closer to Mozart's setup in emphasizing that the teacher must take care of the pupil's knowledge of music in tandem with technical proficiency. Both authors learned the lesson from the Conservatoire's democratization of violin playing and placed the student in physical contact with the instrument from early on. Yet, they also bring back the question of how the student acquires technical versatility alongside musicianship, expression, and the knowledge of music's symbolic code.

Partly, their manuals react to different social and educational settings. Baillot still could rely on the Conservatoire as backing up instrumental teaching. Pupils trained in solfège elsewhere. Conveying theoretical knowledge of music and note reading was, in this context, not necessarily part of the violin pedagogue's tasks. If Spohr, much like Leopold Mozart, made knowledge of music's symbolic code a prerequisite for playing, this was to some extent due to the lack of such an institutional backing in the German countries. So, as opposed to Baillot, Spohr insisted: "Before the student may be handed the violin, he must first learn to read the notes." ${ }^{18}$ This, however, could be achieved stepwise, the diatonic scale from $g$ to $b^{\prime \prime}$ being considered sufficient for the beginner.

What is important to note in the context of this article is that violin manuals cope in one way or the other with the fact that the student develops the idea of which notes to play in

\footnotetext{
${ }^{17}$ Louis Spohr, Violinschule (Vienna: Haslinger, n.d. [1833]); P[ierre] Baillot, L'Art du violin: Nouvelle méthode (Mainz and Antwerp: Schott, n.d. [1835]). On Baillot's reference to the eighteenth century, see Camilla Bork, "Das Hör-Wissen des Musikers im Spiegel ausgewählter Violinschulen," in Wissensgeschichte des Hörens in der Moderne, ed. Netzwerk "Hör-Wissen im Wandel" (Berlin: De Gruyter, 2017), 233-51.

${ }^{18}$ Spohr, Violinschule, 23.
} 
parallel with the manual ability to produce them. The tutors from the 1830s are particularly interesting in this respect: they address the teaching of individuals, and this occurs against the background of a new target group in a growing middle class. Leopold Mozart also wrote with individual teaching in mind, but had to address the general deficiencies of music education that also concerned professional musicians. The Conservatoire, by contrast, provided a full curriculum in music education distributed over its departments. By the same token instrumental teaching could be singled out as an educational practice in its own right. In Spohr and Baillot's manuals, neither Mozart's strong emphasis on a complete musical education is found, nor is the radical separation of subjects in music education. They write for violin teachers, assuming that teachers mediate the knowledge about violin playing to a much larger group of apprentices who may not aspire to become professional musicians, including an audience of lay musicians such as the Stumpf family.

The biggest challenge in this situation appears to be the intertwining of skills. Spohr and Baillot adopt different strategies for this, but both consciously communicate the correct sequence of steps. Spohr implored potential users of the manual that the order of steps in the first main chapter must be followed. That chapter-preceded by a general introduction that Spohr explicitly allowed readers to skip-interspersed practical exercise with practice in note reading. Rhythm, rests, and measure indications, for instance, were taught after the pupil had played the first simple sequences of notes together with the teacher. In particular, anything that concerns intonation had to be followed strictly. The relentless pursuit of perfection at this point would pay off for teacher and student, he exhorted the reader, since bad habits were hard to eradicate at a later time.

Similarly, it is indicative of this seriousness of purpose that Baillot urged teachers to first read the manual in its entirety. This should enable them to mix three components in teaching: explanation, mechanism, and application. Baillot thus did not advocate a "best" order, but emphasized instead that neither part could be taught separately. He allowed students to try out what they learned, but in this they needed guidance. Here the teacher needed to be aware of the potentially detrimental consequences of incorrect movements. Discussing this perspective, Baillot produced elaborate music examples by, for instance, Boccherini or Viotti in the first chapters in order to explain why a particular feature in playing was necessary. Only much later did he provide the teacher with exercises for the students.

What is particularly striking in comparing Baillot and Spohr is the latter's interest in the role of note reading. The student must learn to read some notes first, but may progress here in parallel to playing. Baillot obviously could rely on music students having learned solfège elsewhere, even though the new tutor of 1835 was not officially sanctioned by the Conservatory, where such a division of labor among music teachers had its origins. ${ }^{19}$ Spohr, by contrast, designed a progression for teaching both together. Yet even though the two manuals seem to diverge in the role they give to note reading and in their views on intonation, they agreed on the musical ear being the arbiter in the process of learning or, as Baillot put it, the "conscience of violin playing." 20

Stumpf's musical upbringing is likely to have been similar to what we encounter in Spohr's manual. He was born in the region of Franconia in Northern Bavaria in 1848, and his most likely violin tutor-one can assume-would have followed both the technical and pedagogical norms of the mid-century. As Stumpf relates, schools taught music at a high level in his hometown, including practical skills. His "conscience" - to put it in Baillot's terms-in any case would have had every opportunity to develop according to the requirements formulated in violin education of his time, a supposition I now explore.

\section{Tone Psychology from the Violin Player's Perspective}

It is tempting to look at Stumpf's two-volume Tone Psychology from the perspective of violin playing. Indeed, some of the key terms that structure the first volume could be used as headers for a manual. In the first part, the "reliability of tone judgments" and their "dependence on exercise,

\footnotetext{
${ }^{19}$ Compare Baillot, Art de Violon, 12.

${ }^{20}$ Ibid., 7.
} 
attention, and fatigue" are followed by a discussion of "tone distance judgments." The second part addresses "tones that occur in sequence." Here, muscle memory is an important topic, as part of Stumpf's comparison between two modes of judging tones: either immediately upon hearing, or helped by individually shaped additional criteria (such as muscle memory). Yet if violin tutors tried to cope with the fact that a child's cognitive and motor processes grow in parallel, Stumpf's objective was to disentangle them in the judgments of adults.

This is to say, of course, that the topic of Tone Psychology is judgment, not tone production. Stumpf's philosophical research concerned the perception and cognition of tones in listening subjects, not in the musician while producing music. So it may be unsurprising that the violin is not particularly prominent in his writings. Yet while violin playing does occur as a reference, this did not function like a model or metaphor in the sense discussed earlier. Stumpf dismissed what was effectively the most common metaphor for the hearing mechanism: the piano. "The assumption of a keyboard in the ear," he wrote, "of small vibrating bodies that lay next to each other and are tuned to different pitches is indispensable for solving some question, for ours it does nothing. ${ }^{\prime 21}$ Nevertheless, he neither ignored nor dismissed the fact that people use concrete musical objects and practices in their attempts to describe mental processes. On the contrary, he took such descriptions literally and tried to analyze their actual system of reference. His experience in violin playing allowed him to assess critically the language used by others for bridging the gap between the physics of sound and the workings of the mind. Key to this approach is Stumpf's notion of mediation (Mittelbarkeit). He defined it as a specific "influence of heterogeneous moments in consciousness that act upon judging some content." ${ }^{\prime 22}$ Such moments might coexist in the mind of the judging individual. When the content to be judged and the heterogeneous moment indeed were co-present in the judging mind with some

\footnotetext{
${ }^{21} \mathrm{TP}, \mathrm{I}, 152$

${ }^{22}$ TP, I, 87. Rollinger: "influence of heterogeneous moments of consciousness upon the judgement of a content."
}

degree of regularity, this would lead to an "experience" of their coexistence, and this experience informed further judgments.

The notion of mediation is important in at least two respects. On the one hand, it distinguished Stumpf from one of the leading trends in psychology at his time, namely associationism. ${ }^{23}$ Stumpf was not interested in following the associating mind. He aimed at taking apart the packages of coexisting components in judgment and to analyze experiences after the connection between, for instance, muscle memory and tonal memory had taken shape. In order to understand whether there was a coexistence of heterogeneous moments in mental operations, he compared the accounts of various informants. Among these were philosophical authors, scientists, colleagues, and finally "experimental subjects," whose previous exposure or mental predisposition Stumpf chose according to the needs of his research. If working on the experimental subjects' mindsets was a matter of much later work, most notably the research on language sounds he published in 1926, in Tone Psychology the method was still taking shape. ${ }^{24}$ The playing of musical instruments surfaced here as particularly convenient for distinguishing groups of informants who based their judgments on different previous experiences. So, on the other hand, being familiar with a particular musical instrument could be seen as heterogeneous content par excellence in judging tones.

Reports about fixed couplings between imagining tones and muscular sensation abounds in the nineteenth-century literature on mental representations of tone and music. Some authors, among them Stumpf's mentor, the Göttingenbased philosopher Hermann Lotze, claimed that imagining a musical note necessarily required imagining oneself singing it. Stumpf quotes Lotze: "No memory of tones or series of tones happens without being accompanied by silent

\footnotetext{
${ }^{23}$ See, e.g., Edwin G. Boring's influential account in A History of Experimental Psychology (New York: The Century Co., 1929|, especially chap. 11, "British Associationism in the Nineteenth Century," 206-36.

${ }^{24}$ In 1926 Stumpf published Die Sprachlaute, cf. n. 4. See Julia Kursell, "Carl Stumpf and the Beginnings of Research in Musicality," in The Origins of Musicality, ed. Henkjan Honing (Cambridge, MA: MIT Press, 2018), 323-46.
} 
speaking or singing." 25 That is, just as one imagined speaking a text while reading it, one would also think of oneself as producing tones that one thought of. Another author, Salomon Stricker, even remarked that he adjusted imagined melodies to his own vocal range, feeling his vocal cords in tension when imagining himself singing in falsetto or transposing an imagined melody by an octave for notes that fall outside this range. In the introduction to his Studies on the Mental Representation of Speech (1880), the philosophizing pathologist Stricker explained: "When I sit inactively, with closed eye lids and lips, letting some verse that I know well pass through my mind and observing my organ of speech, then it seems to me as if I was (inwardly) speaking with along with it. . . . When, instead of the words, I call fourth some tones into my memory, for instance by thinking of a folk tune that is well known to me without its words, then I feel nothing in my organ of speech. Yet I do have a strange feeling in my vocal tract; I seem to be (inwardly) singing along with it." ${ }^{26}$

While praising Stricker's writings, Stumpf proposed a different interpretation of these copresent sensations and acts of imagination. Collecting his own observations and those of further individuals in his surroundings, he noted that the imagination of some muscle movement, most notably in the larynx, occurred in just as many cases as did the imagination of tones that were not accompanied by such movements. Stumpf reported that he found himself able to imagine timbres that he could not have produced through singing, as well as pitches

\footnotetext{
${ }^{25}$ Lotze, Medicinische Psychologie (1852): 480, quoted after TP, 154.

${ }^{26}$ Stricker Sprachvorstellungen, 1-2. "Wenn ich ruhig sitze, die Augenlieder und die Lippen schliesse, dann irgend einen mir wohlbekannten Vers durch meine Gedanken ziehen lasse und dabei auf meine Sprachwerkzeuge achte, so kommt es mir vor, als wenn ich (gleichsam innerlich) mitreden würden. . . Wenn ich statt der Worte Töne in Erinnerung bringe, wenn ich also z.B. irgend eine mir wohlbekannte Volksweise (wortlos) durchdenke, so merke ich in den Sprachwerkzeugen nichts. Wohl aber habe ich ein eigenthümliches Gefühl im Kehlkopfe; es kommt mir vor, als ob ich (gleichsam innerlich) mitsingen würde." Viktoria Tkaczyk pursues the aspect of muscular sensation in speech perception and imagination further within the history of theater studies in "Whose Larynx Is It? Fields of Scholarly Competence around 1900," History of Humanities 3.1 (2018): 57-73.
}

without a particular timbral quality that he could transfer from one instrument to the other in his imagination. In other cases, he consciously activated his muscle memory, willingly translating a tone he wished to memorize into muscle movements of his larynx.

A group of informants who, according to Stumpf, did not imagine muscular movements were the string players he knew. Two professors and two lecturers who played the violin and cello assured him "with utmost decidedness" that they perceived no muscular sensation when thinking of tones and based their judgments of tones exclusively on the sounds themselves; no other criteria came into it. All informants were reliably able to determine the key of a piece or pitch of a tone, Stumpf added. ${ }^{27}$ So while previous musical experience often occurred as heterogeneous "co-imagination," it was not a prerequisite for imagining tones. Expert listeners-defined somewhat loosely, through their exposure to more than one musical activity or their outstanding ability in recognizing musical features-replied (in answer to Stumpf's inquiry about their imagination) that they did not notice any sensations in their vocal tract when thinking of tones and music.

Experiments did not confirm that muscle memory would necessarily be an aid in determining pitch. There was no evidence, for instance, that muscle memory was more precise than a memory for tones independent from it. A contemporary experiment, in which the precision of three people was recorded with a visual registration device, revealed that professional singers were not necessarily more precise in repeating the pitch; one of them, a bass, produced so much "oscillation" that the curves registered from his singing had to be dismissed. The experimenter himself-who had sharpened his ear through violin playing, as Stumpf readily explainedproduced the best results. ${ }^{28}$

String players, in particular, seemed to form a group that was independent of such co-occurrence. This held for the string players in Stumpf's surroundings, who claimed to function independently from muscle memory

\footnotetext{
${ }^{27} \mathrm{TP}, 159$.

${ }^{28} \mathrm{TP}, 164$.
} 
when imagining or judging tones. (He related the information he gathered from colleagues with whom he had been playing string quartets, as he would later report in his autobiography. $)^{29}$ In a curious case the opposite seemed to hold. One pupil of a conservatory director proved incapable of playing the violin due to his inability to sense and memorize the necessary movements. He continued to play inaccurately while claiming to detect the inaccuracy. No one believed him, but for the sake of friendliness-to him or to his teacher-that student was not dismissed as "unmusical" but transferred to a piano teacher. In next to no time-we learn-he not only proved to be a capable player but also was able to judge and describe what he heard correctly. Stumpf presumed that this must have been the result of an abnormally weak resolution in the sense of muscle movement. ${ }^{30}$

"One may assume," Stumpf concluded, "that the sensations and imaginations in the vocal tract occur mainly in singers and music lovers who often 'sing a little' as a habitual accompanying feature." ${ }^{\prime 31}$ The main outcome of such investigations was that in mediated judgment, practice and judgment related in accidental ways. The run-of-the-mill music lover associated singing with tonal judgment, the thoroughly educated string player would not, nor would the expert musician, whereas some listeners with advanced reflecting proficiency eloquently advocated mediation as a necessary component in judgment. Given the range of different experiential backgrounds, mediated judgment pointed to interesting divergences among groups of subjects, rather than to a mental function that was shared among all individuals.

\section{TONE AND JUdgment}

What the discussion of muscle memory demonstrates most clearly is that Stumpf seemed to be more interested in the divergences between the groups that base judgment on experience other than muscle memory. One

\footnotetext{
${ }^{29}$ Stumpf, The Origins of Music, 196.

${ }^{30}$ Compare TP, I, 292-93.

${ }^{31} \mathrm{TP}, 160$.
}

such group was that of string players, who apparently were independent from muscle memory in their judgments - in contrast to piano playing, as one gathers from his scathing remark: "Even someone born deaf can learn to play the piano. The visual presentations of the keys and notes need only to be associated with the muscular presentations. ${ }^{\prime 32}$ Two distinctions that were relevant for Stumpf's project of Tone Psychology interlace here. One relates to learning a particular instrument, the other concerns the ability to learn music more generally.

For Spohr, these two questions were identical. According to him, the teacher's role also comprised helping eager parents in deciding whether the violin was the right instrument for their child. The teacher was to screen progress from the very beginning. If the child turned out to have an insufficiently precise musical ear, an instrument in which intonation was given - such as the piano-was to be chosen. Spohr comforted his readers, claiming that a good teacher would be able to give a realistic estimate about a child's talent within a few months.

Baillot eschewed such direct contact with parents. As with solfège, selection could be assumed to happen elsewhere. Instead he highlights the question of the musical ear's function in learning, explaining: "In our musical system there is a relation between the intervals-a material order which has no better judge than the ear: the ear is the conscience of the sounds, it informs us about anything that maintains this order and warns us of all that disturbs it." ${ }^{\prime 33}$ Both a judge in the courtroom of music and the pupil's consciousness in the absence of the teacher, the "musical" had to be developed as a control. The ear was trusted with deciding what is correct and false, good and bad. Coming back to Stumpf's question discussed earlier, one could say that the ear trained muscle memory, rather than, as with singing, muscle memory aided intonation. In practice, the apprentice did get help from the instrument-presuming that it is

\footnotetext{
${ }^{32} \mathrm{TP}, \mathrm{I}, 294$ (trans. after Rollinger).

${ }^{33}$ Baillot, L'Art de Violon, 8: "Dans notre systême musical, il existe un rapport entre les intervalles, un ordre matériel qui n'a point de meilleur juge que l'oreille: l'oreille est la conscience des sons, elle nous avertit de ce qui entretient ou de ce qui trouble cet ordre materiel."
} 
Um sich der Reinheit zu versichern,muss man die lee_ ren Saiten zuRathe ziehen,wie es hier unten angezeigt ișt .

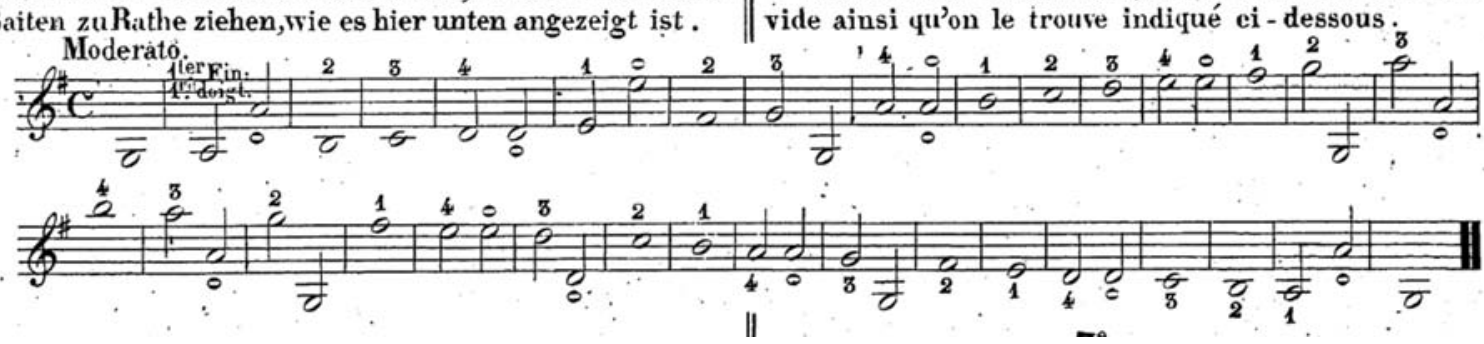

Plate 1: Exercise for verification of pure intonation after Baillot. Source: Baillot, Art du violon, 21.

properly tuned. Baillot consistently advocated checking the intonation by "consulting" the open strings to ensure the "purity" of intonation, as demonstrated in one of the early exercises, reproduced as plate $1 .{ }^{34}$

By contrast, Spohr restricted beginners to equal temperament, although he declared intonation to be the central issue. Speaking of the students' "pure intonation," he explained, "we of course presume equal temperament, since there is no other intonation for modern music. The beginner needs to know no other than this one." ${ }^{35}$ Obviously a more refined intonation would come later, with the student's growing skills. Both Spohr and Baillot provide exercises accompanied by a second violin (to be played by the teacher), adding context to the pupil's intonation.

Violin manuals such as Baillot's and Spohr's refer-in one way or the other-to processes of selection. Not just any student was able to pick up the violin. Successful students would develop a fine musical ear for the desired "purity" of sound, without which the entire process would not make sense. Stumpf's argument, in turn, resorts to this distinction when he singles out string players as particularly competent listeners. String players demonstrate that a fine ear does not result from a fine muscle memory. A decent ear can be tied to a failing muscle sense,

\footnotetext{
${ }^{34}$ Baillot, Art du Violon, 21. He later on points to double fingering as indicating the advice to check the position of the finger against the empty string (26).

${ }^{35}$ Spohr, Violinschule, 3n.
}

which may result in the inability to learn the violin, as happened in the case of the student who switched to the piano. The two senses are torn apart, and their combination in the individual must be seen as accidental.

The decision of which instrument to choose is thus linked to the question of whether an individual has talent or not, which in turn resonates with Stumpf's work in even more important ways than the discussion of muscle sense. This second aspect returns in the distinction between musical and unmusical individuals. This distinction would form the basis of his method. A total negation of musicality complied best with the logical requirements of his philosophical approach to studying the musical mind. In order to distinguish what a musician's mind does, the first question to be asked was: what is the shared ground in any human mind? Even an individual who would not appreciate music, let alone play it, shared the same conditio humana with those who do.

The distinction of being either capable or incapable of denoting what one heard became crucial for the entire project of Tone Psychology. Having examined individuals with little or no talent for music for the first time while professor of philosophy at Würzburg, Stumpf realized that this group promised a new approach to judgment. If his first question had been whether tone judgments as such are "reliable," this group demonstrated that some individuals are incapable of the judgments he expected while still having some judgments that fell outside musical categories. In his work on the subject—after the second 
volume of Tone Psychology in 1890, two major articles followed in 1898 and $1911^{36}$-he made systematic use of the comparison between musically versatile subjects and the so-called amusical individuals (Unmusikalische) or, adopting a Greek euphemism, the amusoi.

Where possible information was given on these subjects' attempts to participate in musical activities. The colleagues, students, and acquaintances who were willing to serve as experimental subjects all had different opinions on music. Some liked music; others were indifferent to it. One in particular declared himself "an enemy of the violin, ${ }^{\prime 37}$ whereas an educated elderly lady, while being incapable of distinguishing between pitches, enjoyed concerts and declared a preference for string quartets, since these seemed "the least boring." ${ }^{\prime 38}$ Yet another, a certain Dr. H., told Stumpf that he had never sung, but played the violin regularly, with some pleasure. This individual appeared to be incapable of dealing with simultaneous sounds and excelled in quirky explanations of what he heard when exposed to them. He believed a successively played octave to be two tones of the same pitch, then he realized the greater distance among them and protested that the confusion might result from his dislike of the octave. Stumpf commented: "The real musician will read such explanations with an incredulous shake of the head. But I am convinced that more than half of those active in music would do even more poorly." ${ }^{39}$

Based on such observations, Stumpf undertook a comparison of judgments that built upon two major resources: the philosophical tradition and the much younger tradition of psychological experiment. The former required carefully distinguishing among categories of judgment, while the latter provided inspiration for how to link philosophical deliberations to empirical research.

\footnotetext{
${ }^{36}$ Compare "Konsonanz und Dissonanz," Beiträge zur Akustik und Musikwissenschaft 1 (1898): 1-108, and "Konsonanz und Konkordanz: Nebst Bemerkungen über Wohlgefälligkeit musikalischer Zusammenklänge," Beiträge zur Akustik und Musikwissenschaft 6 (1911): 116-50.

${ }^{37} \mathrm{TP}, \mathrm{I}, 314$.

${ }^{38} \mathrm{TP}, \mathrm{I}, 317$

${ }^{39} \mathrm{TP}, \mathrm{II}, 367$. In this article, I will not explore such statements from the point of view of today's research in music cognition, which might make them seem less "quirky."
}

Stumpf's experiments were carried out at a time when psychology was not a university discipline in its own right-he would become one of its founders-and when no standards for experimentation were established with regard to the use of statistics, reliability, and potential repetition, for instance. Most strikingly, this method mined the explicit statements of individuals for research that was meant to reach beyond the level of the individual.

Stumpf's approach to the group of non-musical individuals resembles what is nowadays called a control group: in one group of test subjects a certain condition is diagnosed, which the control group is considered not to have. Observations that are considered relevant for the condition can then be checked against the group without the condition. ${ }^{40}$ The main distinction he applied for forming the groups was that between individuals with and without a musical ear. This meant that one group had access to the "musical" features of music, while the other did not. In contrast to the control group, which supposedly allows for checking pathological states against those deemed normal, the comparison among musical and unmusical individuals leaves open for today's reader which of the two groups has "the condition." What is clear is that the musician's mind at work can only be singled out as active against a mind in which that same activity does not occur. One group detects something the existence of which the other negates. In times when the concept of a control group did not exist, Stumpf's method emerged from adapting a logical consideration to the empirical method of observation and inquiry.

\section{Intonation as a Mental Fingerboard}

In sum, judgment lent a model for experimental testing, as earlier research had demonstrated. While in Göttingen, Stumpf became acquainted with the beginnings of psychophysics. Gustav Theodor Fechner, who coined the term in his Elements of Psychophysics (1865), was visiting

\footnotetext{
${ }^{40}$ Trudy Dehue, "History of the Control Group," in Encyclopedia of Statistics in Behavioral Science, ed. Brian S. Everitt and David C. Howell (Chichester: John Wiley \& Sons, 2005), II, 829-36.
} 
Göttingen University when Stumpf obtained his habilitation (the professorial second degree) there with Hermann Lotze. Stumpf participated in some of Fechner's experiments, and he also met the Weber brothers, i.e., the physicist Wilhelm and physiologist Eduard as well as the oldest of them, physiologist and anatomist Ernst Heinrich. The latter had for the first time proposed a method for studying experimental subjects. Applying the two ends of a compass on the subject's skin, he asked whether they were felt horizontally or vertically distant. This allowed him to estimate the subject's acuity in the sensation of touch and the supposed structure of the nerves enabling it, while at the same time checking the reliability of the subject's enunciations. ${ }^{41}$

If Ernst Heinrich Weber's aim was to research neural anatomy and to better understand it in actu rather than post mortem, Fechner developed a method that related measurable physical entities to judgments. Fechner's aim in so doing was to understand whether there were scales in sensation that could be related to measurements in physics. Transferring such measurement to the realm of tones proved more difficult than expected. ${ }^{42}$ Frequency was known to increase exponentially with a sensation rising linearly in pitch. In other words, raising the pitch by an octave required twice the frequency, an increase of two octaves four times the frequency, etc. Frequency, it seemed, confirmed what later came to be known as the Weber-Fechner law: a linear increase in sensation corresponds to an exponential growth in physical measurement of the sensed content.

Yet this approach was of little help for music. Not only did it fail to answer Stumpf's question about judgment as a cognitive activity. Psychophysics left the question open of why some

\footnotetext{
${ }^{41}$ On the Weber household, see Jackson, Harmonious Triads (2006); on Ernst Heinrich Weber's experiments, see Christoph Hoffmann, "Haut und Zirkel: Ein Entstehungsherd: Ernst Heinrich Webers Untersuchungen 'Ueber den Tastsinn'," in Ansichten der Wissenschaftsgeschichte, ed. Michael Hagner (Frankfurt/M.: Fischer, 2001), 191-223; idem, Unter Beobachtung: Naturforschung in der Zeit der Sinnesapparate (Göttingen: Wallstein, 2006); Hui, The Psychophysical Ear (especially chap. 1 on Fechner).

${ }^{42}$ See Julia Kursell, Epistemologie des Hörens: Helmholtz' physiologische Grundlegung der Musiktheorie (Paderborn: Fink, 2018), esp. chap. 5 on physiology as compared to psychophysics.
}

individuals thought they could compare tones only by the help of their larynx while others did not; neither did it explain how people came to consider intonation difficult to begin with. For this it was necessary to take a closer look at the notion of judgment in the realm of tones:

The only peculiarity of the judgement-function as such that compels us to assume different kinds of judging is its affirmative or negative character. Yet one can of course distinguish very many classes of judgements depending on what is affirmed or negated. Among these judgeable contents are, to begin with, all absolute contents, especially sensory contents. Affirming or noticing (grasping, positing, accepting) such content is what we call its perception. This can nonetheless be an illusion and is thereby distinguished from knowledge. What is to concern us now, however, is not the noticing of absolute contents, but rather that of certain relations (connections) found in or "between" them. The question as to which and how many basic relations there are may be left aside here. We shall essentially be concerned with four of them: plurality, increase, similarity, fusion. Calling plurality a relation may be permitted here for the sake of brevity. Whoever finds this objectionable, insofar as a relation already presupposes a plurality of members, may designate it as a factual datum [Thatsache] or whatever. It is certainly something perceivable from contents of presentation or in them. We shall call the noticing (affirming, perceiving) of a plurality analysis, while noticing one of the other relations we shall call relating or comparing. ${ }^{43}$

What mattered most here was the distinction between analysis and comparison. Although this distinction was one among kinds of judgments and not among functions, this distinction yielded a prolific experiment when applied to the two groups of subjects who were either capable or incapable of tonal judgment. If mental functions imposed certain restrictions on the object of his research, so did the experiment. The subjects needed to be questioned in such a way as to make their utterances valid. Playing out the affirmative or negative answer to an actual question and the distinction among classes of relational contents, he teased out of these (empirically existing) subjects' utterances a

\footnotetext{
${ }^{43}$ TP, I, 96 (trans. after Rollinger).
} 
distinction between analytical listening and mere sensation. This distinction stands at the basis of the entire project of Tone Psychology. In Stumpf's eyes-and ears-it opened up the vast field of music to the experimenter: "The curious differences between musical and unmusical natures . . . the diversity of tonal phenomena and the wealth of artistic secrets, as well as the many historical changes of the tonal system and the tonal feelings-all this gives the expert as many points of support in his investigations as they give the layperson obstacles." ${ }^{\prime 4}$

With "unmusical natures," a perspective was included that negated all of the musical features perceived by those of a musical nature. This in turn opened up a new method: psychophysics had demonstrated the use of yes-no questions; now Stumpf turned to music in order to contrast the musical mind with a mind for which any of music's features are negated. Stumpf accordingly invented questions for his groups of subjects that apparently challenged the musical mind very little, such as "do you hear one tone or many?" As it turned out, the question was not trivial; it sometimes left even the most expert listeners in doubt about the separately produced notes in the interval of an octave. Rather than explaining the role of the octave in polyphonic terms, Stumpf went on to explore whether such a sensation formed perhaps the basis rather than the exception for the functioning of the mind. His concept of fusion (Verschmelzung) would be based on this notion.

Though published with this finding of fusion already in mind, the first volume of Tone Psychology dealt with a different subject: what Stumpf termed "tone distance." As an outcome of the comparison between the two groups of subjects-musical and unmusical-it shed new light on judging the distinction between a mere distance and an interval as this notion applies to music. What the unmusical subjects lacked was not the ability to discriminate a physically measurable difference in frequency, but a mental scheme to which musically versatile listeners referred any such distances, thereby turning them into intervals and thus into musically

\footnotetext{
${ }^{44} \mathrm{TP}$, vi (trans. after Rollinger).
}

relevant distances. The music experts were not actually characterized by a better sense for discerning frequencies, but by the fact that they always applied this reference scheme.

By the same token, psychophysics was not the appropriate means to grasp what happened in the musical mind, let alone in the unmusical. Stumpf would later engage in a fierce debate with Wundt who applied statistical methods to large numbers of individuals while ignoring whether they heard intervals or merely distance. Stumpf's insistence upon this distinction can easily be misunderstood as a preference for the "expert" or a disregard of statistics. Neither was the case. Instead he realized that his distinction between the ways of judging tonal distance was washed away with this method from the outset.

What characterized the distinctive approach to tone distances in musical individuals was, thus, that they possessed what Stumpf called a "standpoint." ${ }^{45}$ Musical listeners organized notes according to an implicit schema of relationships. They referred to them as intervals. A value on the parameter of pitch would not simply be considered a distance, but referred to points of orientation, i.e., to the closest interval. As Stumpf wrote-in keeping with the spatial metaphor-they found "clear and stable signposts for acoustic geodesy" 46 within the sound space. Nonmusical subjects did not have access to this musical cartography. While the orientation points were clear to one group, the other could not draw upon such an aid. Interestingly, they would not measure distance, but simply got lost in the territory of music.

As Stumpf would later realize, this geodesy was so dominant in the musical individuals that it would even make intervals that did not comply with these prefixed signposts harder to grasp as different from the signposts. When he tried to notate the singing of a British Columbia First Nation Nuxalk he heard that the singer repeated the same unfamiliar pitches consistently, but needed endless repetitions to grasp the deviation,

${ }^{45} \mathrm{TP}, \mathrm{I}, 149$.
${ }^{46} \mathrm{TP}, \mathrm{I}, 150$. 
which a "Bella Coola Indian" named Nuskilusta patiently provided. ${ }^{47}$

Violin pedagogy, in turn, went in the opposite direction. The turn-of-the-century Violin School for Beginners, op. 6, by Otakar Ševčík would propose the diatonic scale be substituted for tempered semitones from the apprentice's very first steps (plate 2). Turning the fingerboard into an equidistant measuring device, Ševčík emulated the state of psychophysics rather than complying with a cartography à la Stumpf. The consequences of understanding equal temperament as a linear scale rather than a system of interval references can be traced up until the burgeoning debate about microtonality in the early twentieth century, when the tobe-avant-garde painter Mikhail Matyushin published a violin school for quarter tones that mimicked Ševčík's system. By contrast, Ferrucio Busoni hoped to find in a microtonality of tones divided into thirds that which a piano could not do-a solfeggio with more steps and a more fluid intonation. ${ }^{48}$

\section{Tune AND TONe}

The quest for a better understanding of the musical geodesy pervades the two volumes of Tone Psychology. As can be expected, the empirical

\footnotetext{
${ }^{47}$ As described in Carl Stumpf, "Lieder der BellakulaIndianer" (Songs of the Bella Coola Indians), Vierteljahrsschrift für Musikwissenschaft 2 (1886): 405-26. See Alexander Rehding, "The Quest for the Origins of Music in Germany circa 1900," Journal of the American Musicological Society 53 (2000): 345-85; idem, "Wax Cylinder Revolutions," Musical Quarterly 88 (2005): 123-60; Gretel Schwörer-Kohl, "Die Musikethnologie Carl Stumpfs am Beispiel der siamesischen Musik" (Carl Stumpf's Ethnomusicology, Using the Example of Siamese Musicl, in Die Sinne und die Erkenntnis (The Senses and Knowledge), ed. M. Ebeling and M. Kaiser-el-Safti (Frankfurt am Main: Lang, 2011), 175-84; idem, "Carl Stumpf und die Anfänge der Musikethnologie in Halle," in Musikwissenschaft 1900-1930: Zur Institutionalisierung und Legitimierung einer jungen akademischen Disziplin, ed. Wolfgang Auhagen, Wolfgang Hirschmann, and Tomi Mäkelä (Hildesheim: Olms, 2017), 66-72.

${ }^{48}$ On Š evčík's op. 6 see, for instance, Michał Burczyk, "Otakar Ševčik—ojciec nowoczesnej pedagogiki skrzypcowej," Prace Naukowe Akademii im. Jana Długosza w Czestochowie. Edukacja Muzyczna 9 (2014): 49-61, here 55; on microtonality in Matyushin and Busoni, see Julia Kursell, Schallkunst: Eine Literaturgeschichte der Musik in der frühen russischen Avantgarde (Wien: Sagner, 2003), 183-90.
}

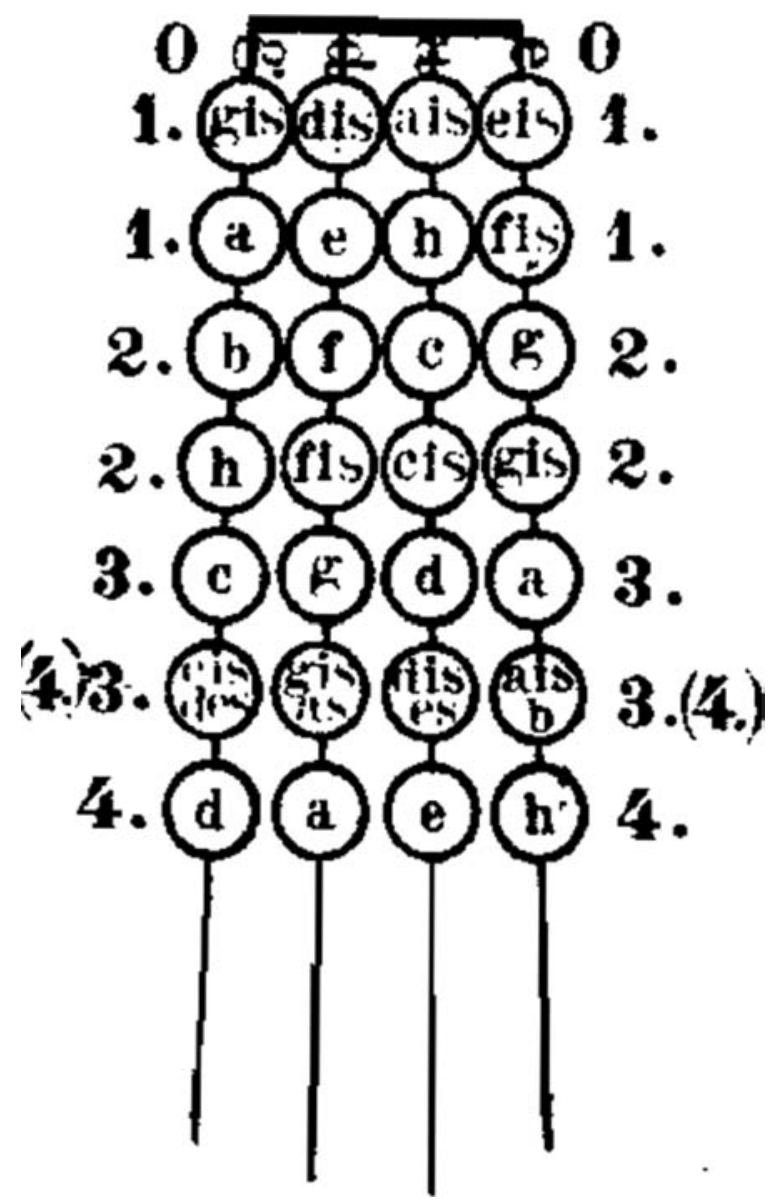

Plate 2: Ševčík's chromatic well-tempered mental fingerboard. Source: O. Ševčík, ViolinSchule für Anfänger, op. 6 (Wien: Universaledition, n.d.), 3.

basis for this quest remained restricted to a notion of music that was fed by the practice of individual musicianship, modified only by various degrees of talent and exposure. Up to Stumpf's encounter with non-European musicians there was no reason to question the validity of the insights he based on the data gathered from this setting. On the contrary, it is remarkable that this research took seriously the utterances of people who lacked the ability to participate in the dominating musical discourse.

Shortly before the encounter with the Nuxalk, Stumpf browsed the literature published in English on his subject. In 1885 he contributed an extensive review of the theories of Spencer, 
Darwin, and the two British psychologists John Sully and Edmund Gurney to the newly founded journal Vierteljahrsschrift für Musikwissenschaft, which-like Guido Adler's opening manifesto for the young discipline "The Scope, Method and Aim of Musicology" - also comprised current research in the systematic rather than historical study of music. ${ }^{49}$

Gurney, in particular, attracted Stumpf's attention. In Gurney's posthumously published treatise The Power of Sound (1880) he posited a "musical faculty" that he defined as follows: "I am assuming here, for the sake of clearness, and without argument, that whatever explanations of musical effect turn out to be possible, the exercise of the musical faculty will present an ultimate and inexplicable element." ${ }^{50}$ For Stumpf, the assumption of such a faculty was problematic in two respects: in that Gurney claimed the "faculty of music" to be un-analyzable, and in that he used it for explaining both the origins of music and music's further development. ${ }^{51}$ Gurney's claim that the music of Beethoven and Wagner and the earliest developments of music could be explained by one and the same unified trait did not convince Stumpf. According to him, Gurney ran into contradictions when he eventually provided further explanation. Stumpf disagreed, in particular, with a footnote, in which he read that Gurney did not understand his musical faculty to refer to "some special sort of musical gift," but rather, to the "ordinary power of perceiving and recognizing tones, of apprehending a melodic form as a whole by co-ordination of its parts." ${ }^{\prime 52}$ This meant that any human possessed a faculty that enabled them to hear, understand, and reproduce melodies.

Yet Stumpf's research had shown the opposite. His experiments had demonstrated that critical features of music were not recognized by every member of even so homogeneous a group as his students, staff, and colleagues in

\footnotetext{
${ }^{49}$ Erica Mugglestone, "Guido Adler's 'The Scope, Method, and Aim of Musicology' (1885): An English Translation with an Historico-Analytical Commentary," Yearbook for Traditional Music 13 (1981): 1-21.

${ }^{50}$ Gurney, The Power of Sound, 86

${ }^{51}$ Stumpf, "Musikpsychologie in England," 331.

${ }^{52}$ Gurney, as quoted in Stumpf, "Musikpsychologie in England," 333-34, my italics; Gurney, The Power of Sound, $123 n$.
}

terms of education and social standing. The geodesy of music was accessible only to some, and it was clearly the result of learning. In his review, Stumpf argued that the "powers" into which Gurney broke down his "musical faculty" were not specific to music. They belonged to sensation and perception in general. As a consequence, the faculties Gurney had assumed to exist could not account for a "musical faculty" in its own right: no innate faculty could be posited that was reserved for appreciating music.

What did not occur to Stumpf was that Gurney did not follow the same approach to melody as did Stumpf the violinist. Rather than positing a capacity to judge tones, Gurney described an "ordinary power of perceiving and recognizing tunes, of apprehending a melodic form as a whole by co-ordination of its parts." ${ }^{\prime 53}$ In modern terms this would be described as the perception of melodic contour, which is necessary for grasping, for instance, intonation in speech. A violinist who is able to understand contour but not pitch not only seemed a contradiction in terms, but also no violin tutor of the nineteenth century would have foreseen a role for the appreciation of contours as a musical feature in its own right-at least not before sound knowledge of tone production and intonation could be taken for granted. Stumpf at this point fell prey to his own predisposition. The small reading mistake became the pillar of his critique.

Perhaps even more interesting against this background are the observations on melodic contour that do appear in his Tone Psychology. The second volume was devoted to the question of fusion (Verschmelzung). The main finding in the research on fusion was that not all listeners are able to distinguish several notes in a chord and that this becomes easier to the same degree as an interval is more dissonant. The ability to distinguish notes was constrained from two sides, in other words. On the one hand, even the most capable individuals sometimes did not discover two notes in an octave; on the other hand, the same capable test subjects failed to securely identify all elements in unfamiliar and complex combinations. Stumpf extensively discusses the ability of the composer and cellist

\footnotetext{
${ }^{53}$ Gurney, The Power of Sound, 85, 123, note, my italics.
} 


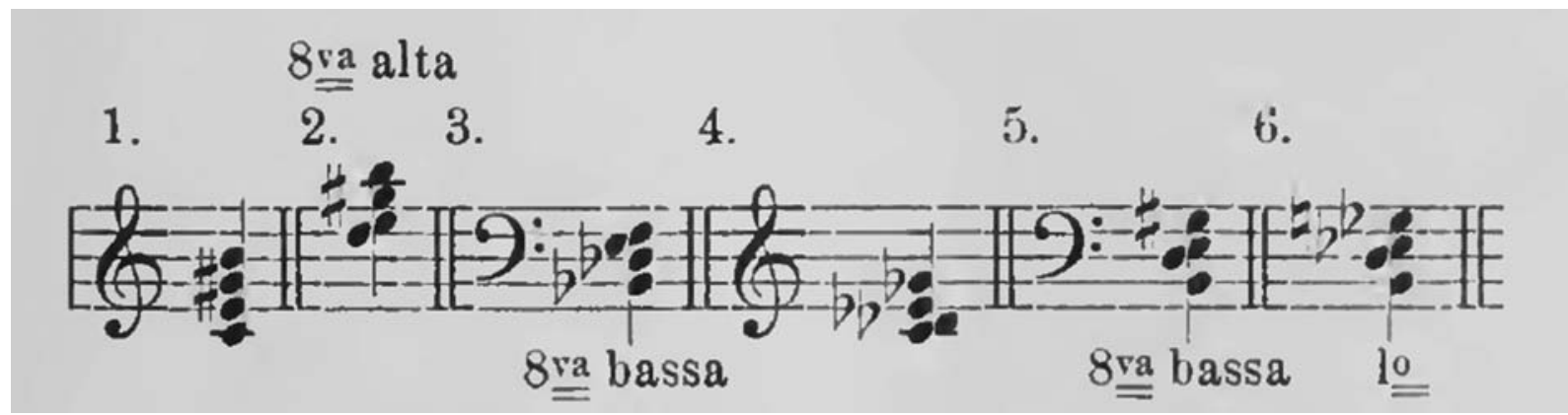

Plate 3: Stumpf's samples of "abhorringly ugly" chords. Source: TP, II, 369.

David Popper, whom he had met in Prague. He put to test the musical ear of this prominent subject, exposing him "only briefly" to "exceedingly difficult" chords (plate 3).

Stumpf adds that he himself had slightly better results for the "abominable constellation no. 7," and was able to identify at least the highest notes in even more "detestable malformations. ${ }^{154}$ Summarizing the results from such challenges, he explained: "In more conventional constellations-how starkly dissonant they may be-a larger number of simultaneous tones can be recognized. And even in the most unconventional ones, those discussed earlier [i.e., those in ex. 1] things change when they appear amidst a musical progression. One is prepared then by what precedes them, together with the possibilities of voice leading that one knows from experience to the new that is coming and even expects it." ${ }^{\prime 55}$ This task, namely the recognition of a tone in a compound, also formed the basis for the next step in Stumpf's argument. From "hearing out" tones (Heraushören) he went on to discuss the properties of the compound in relation to its parts. Assuming the existence of "analyzed compounds" such as chords whose composition was clear to the subject, he inquired after the properties of such compounds. A chord, for instance, was granted properties that one would expect to apply exclusively to single notes, such as pitch. From here, the question ensued whether and how listeners detected voices within sequences of such compounds. Stumpf defined voice as follows:

\footnotetext{
${ }^{54} \mathrm{TP}, \mathrm{II}, 369-70$.

${ }^{55}$ TP, II, 370.
}

We assume "voice" to be, in the first instance, the sequence of tones that is built from homologous parts in chords; i.e., for instance, the highest, second highest, in each of them. This is not the definition of voice in the musical sense, for which a homogeneous connection between tones in a sequence is essential, while the tones connected in that way are not always homologous. Yet, we do not deal with the necessary conditions and rules for musical listening but with the relevant acoustic phenomena more generally. ${ }^{56}$

Ernst Mach had experimentally discovered a distinction between two modes of listening in $1885 .{ }^{57}$ As plate 4 shows, two chords in which the upper voice remained on the same pitch seemed to change in pitch when he fixed his attention to the changing voice, yet they only appeared to change in timbre (Klangfarbe) when, instead, he fixed his attention to the stable upper voice. $^{58}$

For Stumpf, this was a matter of "inconsequence"-the listener sometimes experienced the coexistence of two simultaneous perceptions, one of which could admittedly be false. In "practical music," that is to say in examples taken from the canon of classical music, this phenomenon played an important role. Two examples illustrate his point: in Beethoven's Fifth Symphony, the reprise of the main theme

\footnotetext{
${ }^{56} \mathrm{TP}, \mathrm{II}, 393$

${ }^{57}$ Ernst Mach, Contributions to the Analysis of the Sensations, trans. C. M. Williams (Chicago: Open Court Publishing, 1897).

${ }^{58}$ See on this point the discussion in Alexandra Hui, The Psychophysical Ear. Hui rightly emphasizes that such an example requires a readership who is educated in music to begin with.
} 


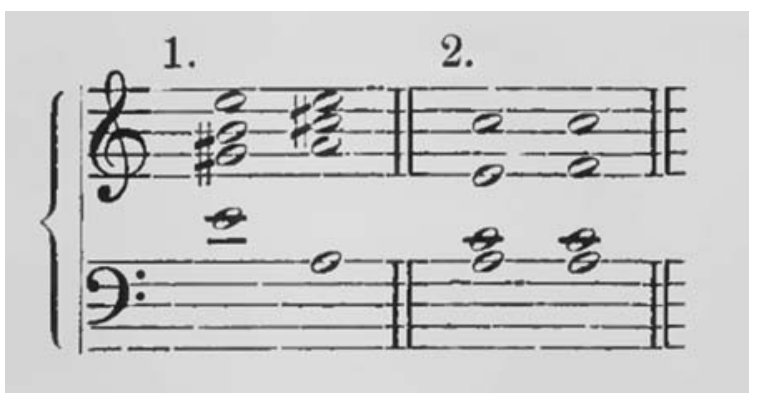

Plate 4: Mach's experimental sample for comparing spectral and tonal listening to chord progressions as reproduced in Stumpf's Tone Psychology. Source: TP, II, 393.

is given to the entire orchestra except the first flute, first oboe, trumpets, and timpani. "This does not escape the musical ear," Stumpf noted, "yet, the entire mass of sounds seems to plunge down." A better example was found in the beginning of Schubert's String Quartet in D Minor: again the entire mass of sounds seemed to be descending, although the bass and upper voice were immobile. "The deception is by no means complete and this effect not intended by the composer, who had, in that case, simply made all voices descend. Also, the effect diminishes when listening to it more often as well as through becoming better acquainted with the score. Yet it never fades completely. ${ }^{\prime 59}$ Both instances are reproduced in Tone Psychology (plate 5). After enumerating more examples of this kind, Stumpf concludes by saying that once we notice the phenomenon, it appears everywhere.

This discussion inserts melody into a completely different framework to that which appeared in Gurney. Stumpf did not abstract from an ability to analyze compound sounds into notes, as Gurney did, nor did he accept the switch between two modes of recognition as it is conceived of by Mach. He took the single tone as his point of departure to proceed from there to a tonal distribution of notes, and from there further on to simultaneous notes and finally to sequences of chords.

\footnotetext{
${ }^{59} \mathrm{TP}, \mathrm{II}, 395$.
}

In the 1848 novella Der Arme Spielmann, the Austrian playwright Franz Grillparzer introduces the fictive narrator as strolling through Vienna's outskirts. Near the Prater he encounters a strange individual that attracts attention, especially that of children who make fun of him. The middle aged and apparently very poor man plays the violin with great affection. Yet the narrator cannot believe his ears. What this individual plays is utterly unmusical. He becomes interested in that strange musician and eventually seeks him out to learn about his strange story: a love of music that did not become expressed. The unlucky musician's good nature eventually brings about his death in a flood when he tries to save the child of a young widow, a neighbor whom he secretly loves.

The fictive, unsuccessful violinist epitomizes the figure of Stumpf's amusical subject. These unhappy lovers and haters of the violin were all being taken seriously in their tonal judgment by the experimenting philosopher, but who only aimed at understanding the proper violinists. The unmusical subjects themselves were not yet given a voice to express how they, after all, experienced what they heard. They helped explain the condition of being musical, and for Stumpf that meant mapping tones with an imaginary fingerboard that was as flexible as that of the violin and as rigorous as the violin teacher.

The extent to which Stumpf drew on his musical upbringing in this research only came to the fore when he encountered recording technology. Although he eventually advocated the use of phonographic recording, he never fully accepted the technology because of the way it exposed its listeners to "unanalyzed" sound (Stumpf's term). The phonograph enabled research that used the ambiguity of phenomena systematically: the researcher could listen to the recorded item repeatedly, embracing a different standpoint and research question in every round of listening. By renewing the question of whether perception contains only that which is consciously present or also that which might give rise to a different interpretation in consciousness, he could not follow his young colleagues who did not bother to ascertain whether these other potential 


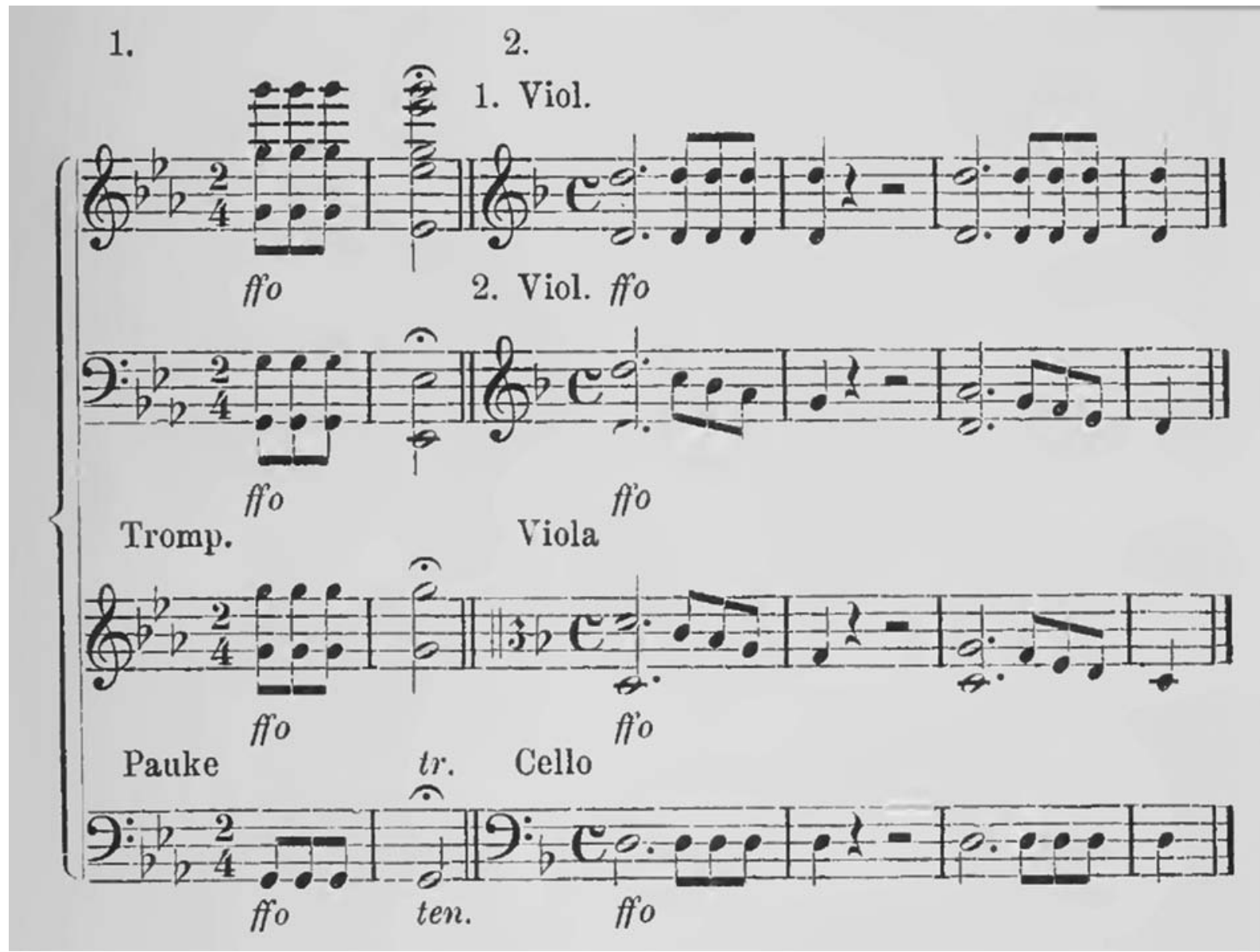

Plate 5: Two examples for contradictory impressions of stable versus descending pitch, taken from Beethoven, Symphony No. 5 in C Minor, op. 67, first movement; and Schubert, String Quartet in D Minor, D. 810, first movement. Source: TP, II, 395.

interpretations were present-in sensation or on a phonographic cylinder.

Looking back at the findings in Tone Psychology, the violin fulfills several roles. It connects Stumpf to a musical activity that is deeply immersed in the musical life of nineteenthcentury central Europe. His participation in musical education and concert life took him from small towns in Franconia where he grew up, via Würzburg and Göttingen where he studied, and back first to Würzburg and later to Prague, Halle, Munich, and eventually Berlin, where he held positions as Professor of Philosophy and Director of the Institute of Psychology. He always actively participated in these towns' musical life, engaging in chamber music activities through, for instance, playing quartets with his colleagues, and working with local celebrities in music life such as Popper or Josef Joachim.

These activities return in the crucial role that his research ascribes to the presence and absence of a tonal grid of interpretation in the minds of his informants and experimental subjects. This links up to the way in which, in violin playing, intonation instantiates a pattern of reference points that is acquired together with the skills of producing tones. Such a grid-the geodesy of tonal space-became Stumpf's model for explaining the workings of the mind, more so than any instrument.

Yet beyond the physical fingerboard, it is important to note that the violin requires the student to mentally master the grid. This raised 
the question of whether and how one could still modify that which is acquired. Once mastered, the grid also imposed itself on future interpretations, as he well understood. Not only did Stumpf rarely miss an occasion to include his own reactions to the experimental tasks he invented, but he also very frankly described his insights as stemming from encounters with utterly unfamiliar tasks. Transcribing Nuskilusta made him aware of his own mental preset, while reading Mach made him reinterpret the music of Beethoven and Schubert.

The threshold Stumpf did not breach eventually came with recording devices. He could not accept that a tune could be accepted as something that is accessible to those who do not possess the concept of tone. The ability to apply the schema of tonality, once acquired, was not something one would easily get rid of again, as Stumpf could see when his informants proved unable to judge tonal distances not according to tonality. He himself would feel this difficulty when he first encountered non-European musics. If the consequences for tonal judgment were graspable by his analytical mind, he did not follow a younger generation of researchers at his institute who did not possess the rigid education of music listeners through playing music themselves. For his assistants, music would more and more become something that one listens to in the first instance. Sunt certi denique fines-thus Grillparzer's hero quotes Horace in Der arme Spielmann, packing up his instrument. ${ }^{60}$

\footnotetext{
${ }^{60}$ Franz Grillparzer, "Der Arme Spielmann," in Sämtliche Werke, ausgewählte Briefe, Gespräche, Berichte, ed. Peter
}

\section{Abstract.}

This article investigates the work of philosopher and experimental psychologist Carl Stumpf with a focus on embedding his scientific perspective in a practice of musicianship. Stumpf wrote in an autobiographical essay from 1924 that he had considered becoming a professional violin player before taking up the study of philosophy. I claim that the practice of learning and playing this instrument sheds light on his concept of music, and at the same time signals its relevance for nineteenth-century musical aesthetics. To carve out the role of Stumpf's musicianship, I propose a "psychoanalytic" approach of tone psychology in the sense of Gaston Bachelard. For this I read through Stumpf's writings to trace the function and role of practices like analyzing tones and tunes, memorizing and notating pitch and melody, and using related tools and techniques like phonography. This is held against a reconstruction of his mentioning of the violin and of the context of violin pedagogy in the mid-nineteenth century. In so doing, I hope eventually to sharpen the notion of tone in Stumpf and thereby to contribute to a better understanding of his concept of complex qualities as opposed to the notion of Gestalt in the generation of his students. Keywords: Stumpf, tone, violin, theory, pedagogy, tune

Frank and Karl Pörnbacher (Munich: Hanser, 1964), vol. 3: Satiren, Fabeln und Parabeln: Erzählungen und Prosafragmente: Studien und Aufsätze, 146-86, here 150. 